\title{
Urban Horticulture, from Local Initiatives to Global Success Stories
}

\author{
Roland Ebel $^{1}$, Esmaeil Fallahi ${ }^{2}$, John L. Griffis, Jr. ${ }^{3}$, \\ Dilip Nandwani ${ }^{4}$, Donielle Nolan ${ }^{5}$, Ross H. Penhallegon ${ }^{6}$, \\ and Mary Rogers ${ }^{7}$
} ADDITIONAL INDEX wORDs. botanical gardens, chinampa, collective action, farmer-
to-farmer program, urban agriculture

SuMmary. Urban horticulture describes economically viable horticultural production activities conducted in a city or suburb. It is a growing segment of horticulture in the United States as well as in developing countries, where the enormous growth of megalopolis is not backed by a simultaneous increase of farmland or agricultural productivity. Today, urban horticulture includes food sovereignty in underprivileged neighborhoods, increased availability of vegetables and fruits in big cities, healthy and diverse diets, improved food safety, low transportation costs, efficient resource use, and the mitigation of environmental impacts of horticultural production such as the emission of greenhouse gases. The workshop "Urban horticulture: From local initiatives to global success stories," held at the 2018 American Society for Horticultural Science (ASHS) conference in Washington, DC, featured present and historical success stories of urban horticulture from Asia, Africa, Latin America, and the United States.

$\mathrm{U}$ rban horticulture brings together what used to be widely separated: food production and urban space. In a broader sense, urban horticulture encompasses everything from small home and community gardens to city park management, rooftop and wall greening, as well as complex vertical farms. In a narrower sense, noncommercial uses are excluded, and the term refers to economically viable horticultural activities

Received for publication 17 Oct. 2019. Accepted for publication 18 Nov. 2019.

Published online 31 December 2019

${ }^{1}$ Montana State University, Department of Health and Human Development, MSU Campus Reid Hall 345, Bozeman, MT 59717

${ }^{2}$ University of Idaho, Department of Plant Sciences, 29603 U of I Lane, Parma, ID 83660

${ }^{3}$ Department of Ecology and Environmental Studies, Florida Gulf Coast University, 10501 FGCU Boulevard S., Ft. Myers, FL 33965

${ }^{4}$ Tennessee State University, Department of Agricultural and Environmental Sciences, 203 Lawson Hall, Nashville, TN 37209

${ }^{5}$ George Mason University, Office of Sustainability, 4400 University Drive, Fairfax, VA 22030

${ }^{6}$ Oregon State University Extension Service, $950 \mathrm{~W}$. 13 Avenue, Eugene, OR 97402

${ }^{7}$ Department of Horticultural Science, University of Minnesota, 305 Alderman, 1970 Folwell Avenue, St. Paul, MN 55108

R.E. is the corresponding author. E-mail: roland. ebel@gmx.com.

This is an open access article distributed under the CC BY-NC-ND license (https://creativecommons.org/ licenses/by-nc-nd/4.0/).

https://doi.org/10.21273/HORTTECH04525-19 that are conducted in a city or suburb (Ohyama et al., 2008).

The concept of urban horticulture is widely congruent with the terms urban agriculture or urban farming. Urban horticulture is both a site characterization and a production strategy. During the past decade, the idea has left the circles of producers and scholars and has become increasingly popular in political discussions, especially in the face of global population growth. With a world population of 9.6 billion by 2050 , an ongoing urbanization process (today, more than $50 \%$ of the world's population live in cities; by 2030 , this number will rise to $70 \%$ ), and a simultaneous decrease in availability of arable land in rural areas, urban farming has become an increasingly popular alternative to land-extensive rural food production. As a result, today, at least 100 million people worldwide are dedicated to urban farming; and with potential yields of up to $50 \mathrm{~kg} \cdot \mathrm{m}^{-2}\left(10.2 \mathrm{lb} / \mathrm{ft}^{2}\right)$ per year and more, vegetable production is the most productive component of urban farming (Eigenbrod and Gruda, 2015).

Urban horticulture offers numerous benefits, especially in the fields of 1) consumer health and nutrition, 2) environmental consequences, as well as 3) economic advantages and resource efficiency.
Urban horticulture is expected to have positive impacts on nutrition quality and health. The global nutrition transition describes large changes in dietary and physical activity patterns of rural dwellers in developing nations migrating to urban areas (Pinstrup-Andersen, 2019). The amount of physical activity of these migrants declines while they concurrently change their nutrition habits, often culminating in a "western diet" (high intake of fats, added sugars, animal-source foods, and refined carbohydrates). A global trend toward obesity and diabetes is the result (Popkin, 2015). Although various factors (such as consumer preferences, incomes, and food prices) determine the dietary transition, access to food is crucial. In many of today's megacities, a few supermarkets have replaced the formerly omnipresent open markets. Consequently, the physical access to fresh horticultural produce has become the most limiting factor for consuming healthy food. Locally produced and sold horticultural products increase the access to diversified, healthy diets available throughout the year. In addition, local production decreases transport and storage time and, therefore, minimizes food safety risks (Pinstrup-Andersen, 2019).

Bringing producers and consumers closer together has environmental benefits. Shifting food production to locations with high demand reduces the emission of greenhouse gases. To date, the amount of emitted carbon dioxide by transporting fruits and vegetables is comparable to or greater than the amount emitted during the production process (Ohyama et al., 2008).

In economic terms, less transportation means fewer transportation costs, and urban horticulture can help revitalize unused areas and deteriorated neighborhoods. Finally, urban horticulture is characterized by a high resource efficiency and productivity per area. Thanks to the frequent use of hydroponics and fertigation, water and nutrient recycling rates are elevated (Pinstrup-Andersen, 2019). For an even more sustainable production in the future, low-input systems such as organoponics (system of urban agriculture using organic gardens, popular in Cuba) will play an increasingly important role (Eigenbrod and Gruda, 2015). 
Regarding limitations of urban horticulture, most systems are still expensive. The high initial investment is a limiting factor, especially in developing countries. Rising land prices and urban pollution are further constraints to the expansion of urban horticulture (Eigenbrod and Gruda, 2015).

Our series of publications highlights success stories of urban horticulture from all over the world. It is the result of the workshop "Urban horticulture: From local initiatives to global success stories," held at the 2018 ASHS conference in Washington, DC. The workshop was as diverse as urban horticulture itself. There were presentations about the booming urban horticulture scene in Asia, teaching urban permaculture to students in Virginia, and training small farmers in Tajikistan and Kyrgyzstan how to prune their fruit trees. In the current series, we feature urban horticulture in Iran, Mexico, Senegal, and the city of Minneapolis, MN.

Despite being a current trend, urban horticulture has a history of more than 3000 years. "Ancient Urban Gardens of Persia: Concept, History, and Influence on Other World Gardens" by Esmaeil Fallahi, Pontia Fallahi, and Morteza Khosh-Khui brings us back to one of its origins, Persia, where gardens and green spaces have historically played a significant role for culture and history. Each Persian botanical garden represents a wide range of germplasm of fruits, ornamentals, and other horticultural plants, which constitutes the relevance of these outstanding systems for today's horticulture.
Similar historic achievements were made in Mesoamerica: The socalled chinampas (which can still be found south of Mexico City) are raised fields on a small, artificial island on a freshwater lake surrounded by canals and ditches. The canal water rises through capillarity to the crops and reduces the need for irrigation. Yearly, chinampas allow up to seven harvests of vegetables and ornamentals. Learn more about chinampas and how these agroecosystems may be used in the cities of our times in "Chinampas: An Urban Farming Model of the Aztecs and a Potential Solution for Modern Megalopolis" by Roland Ebel!

Although most of the discussion about urban horticulture refers to food, the concept naturally also includes ornamentals produced in cities. As urban areas in countries such as Senegal expand and modernize, the demand for ornamental plants increases. "Curriculum Development and Training on Flowers and Ornamental Plant Production Practices in Rural Senegal with Winrock International and the USAID Farmer-toFarmer Program" by John L. Griffis provides insight on a farmer-to-farmer project in Senegal with the goal of training students and farmers in producing ornamentals.

Education is crucial for expanding urban horticulture, in developing countries as well as in the United States. "Growing North Minneapolis: Connecting youth and community through garden-based experiential learning" by Mary Rogers, Illana
Livstrom, Brandon Roiger, and Amy Smith deals with urban agriculture and youth development summer program in a North Minneapolis, MN, neighborhood. Teenagers who face barriers to employment, particularly youth from low-income families, youth of color, youth from immigrant families, and youth with disabilities, were trained by undergraduate students and so-called garden mentors in as diverse fields as horticultural production and cooking. This resulted in a mutually beneficial experience for students and trainees.

Urban horticulture has the potential to change the world's horticultural scenery significantly. Its expansion requires learning from the past, doing research in the present, as well as considering the future by educating farmers and students.

\section{Literature cited}

Eigenbrod, C. and N. Gruda. 2015. Urban vegetable for food security in cities. A review. Agron. Sustain. Dev. 35(2):483498.

Ohyama, K., M. Takagaki, and H. Kurasaka. 2008. Urban horticulture: Its significance to environmental conservation. Sustain. Sci. 3(2):241-247.

Pinstrup-Andersen, P. 2019. Vertical indoor production of vegetables to reduce micronutrient deficiencies in urban areas. UNSCN Nutr. 44(1):188-189.

Popkin, B.M. 2015. Nutrition transition and the global diabetes epidemic. Curr. Diabetes Rev. 15(9):64. 